\title{
PENGARUH PENGGUNAAN MODEL COOPERATIVE LEARNING TIPE PICTURE AND PICTURE TERHADAP HASIL BELAJAR MEDIA PEMBELAJARAN MAHAMAHASISWA SEMESTER IV PENDIDIKAN EKONOMI TAHUN AKADEMIK 2014/2015
}

\author{
Wakijo \\ Pendidikan Ekonomi FKIP Universitas Muhammadiyah Metro \\ Wakijo12umm@gmail.com
}

\begin{abstract}
Abstrak
Tujuan dalam penelitian ini adalah untuk mengetahui pengaruh penggunaan model cooperative learning tipe picture and picture terhadap hasil belajar Media Pembelajaran semester genap pada Pendidikan Ekonomi tahun akademik 2014/2015. Berdasarkan penelitian ini metode eksperimen menggunakan bentuk quasi experimental design nonequivalent control group design. Analisis data menunjukkan hasil belajar Media Pembelajaran mengalami peningkatan $14,81 \%$, dilihat dari perbandingan evaluasi pretes $66,67 \%$ sedangkan mahasiswa yang mencapai kriteria ketuntasan minimal pada evaluasi posttes adalah $81,48 \%$. Berdasarkan hasil penelitian tersebut maka hipotesis dapat diterima sebab $t_{\text {hitung }}\left(t_{\text {hit }}\right)=27,4$ lebih besar daripada $t_{\text {tabel }}\left(t_{t a b}\right)=1,71$ dan 2,48. Dengan demikian menunjukkan bahwa ada pengaruh yang positif Penggunaan Model Cooperative Learning tipe Picture And Picture Terhadap Hasil Belajar Media Pembelajaran mahasiswa I Semester IV Pendidikan Ekonomi Tahun Akademik 2014/2015.
\end{abstract}

Kata Kunci: Model Cooperative Learning Tipe Picture And Picture, Hasil Belajar

\section{PENDAHULUAN}

Tujuan pendidikan merupakan perubahan perilaku yang direncanakan dapat dicapai melalui proses pembelajaran. Hasil belajar adalah hasil yang dicapai dari proses pembelajaran sesuai dengan tujuan pendidikan. Hasil belajar diukur untuk mengetahui pencapaian tujuan

terdapat dua dimensi yaitu dosen dan mahasiswa, kedua pihak ini saling komunikasi terutama dalam kegiatan pembelajarn. Bila kita simak lebih lanjut kedua dimensi ini masing-masing mengalami masalah dalam mencapai hasil belajar mahasiswa yang optimal.di pihak dosen adalah kesulitan memilih model pembelajaran yang tepat dan di pihak mahasiswa kesulitan mencapai pemahaman materi dipelajari.

Upaya ntuk mengatasi permasalahan di atas telah banyak dikembangkan modelmodel pembelajaran untuk mengatasi pihak mahasiwa kesulitan pemahaman materi yang dipelajari, di antaranya adalah dengan mengembangkan model cooperative learning tipe picture and picture. model 
cooperative learning tipe picture and picture merupakan bentuk upaya untuk meningkatkan pemahaman materi mahasiswa yang efeknya diharapkan dapat meningkatkan hasil belajarnya.

Proses pembelajaran merupakan aspek yang sangat penting, sehingga diperlukan variasi-variasi baru untuk dapat menyampaikan isi dari kompetensi yang pada akhirnya diperoleh pengetahuan yang utuh. Penggunaan model cooperative learning tipe picture and picture merupakan salah satu alternative dalam pengembangan model perkuliahan, dimana mahasiswa membangun pemahaman terhadap suatu materi baru berdasarkan kemampuan yang sudah dimiliki dengan mengaitkan pada permasalahan nyata serta memecahkan permasalahan dengan mahasiswa lain dalam proses pembelajaran, sehingga dapat meningkatkan aktivitas belajar pada mata kuliah Media Pembelajaran pada mahasiswa dan dapat meningkatkan hasil belajar mahasiswa.

\section{KAJIAN PUSTAKA}

\section{Cooperative learning}

Cooperative learning adalah "model pembelajaran dengan menggunakan sistem pengelompokan / tim kecil dengan sejumlah mahasiswa yang mempunyai tingkat kemampuan yang berbeda-beda (heterogen)". Sejalan dengan hal tersebut menurut Anita Lie (2004:12) sistem pembelajaran yang memberikan kesempatan pada anak didik untuk bekerja sama dengan sesama mahasiswa dalam tugas-tugas yang terstruktur disebut pembelajaran cooperative learning. Pembelajaran cooperative merupakan suatu cara belajar tanggung jawab dalam mengerjakan sesuatu.

\section{Model Cooperative Learning Tipe Picture and Picture}

Model cooperative learning tipe picture and picture menurut Santoso (2011) adalah suatu metode belajar yang menggunakan gambar dan dipasangkan/diurutkan menjadi urutan yang logis. Sedangkan menurut Sunenti (2013) model pembelajaran cooperative learning tipe picture and picture adalah sebuah model dimana dosen menggunakan alat bantu atau media gambar untuk menerangkan sebuah materi atau memfasilitasi mahasiswa untuk aktif belajar. Menurut Huda (2013:236), sintak langkah-langkah model pembelajaran picture and picture dapat dilihat sebagai berikut:

a) Tahap 1 : Penyampaian Kompetensi. Pada tahap ini, dosen diharapkan menyampaikan kompetensi dasar mata kuliah yang bersangkutan. Dengan demikian, mahasiswa dapat mengukur sejauh mana kompetensi yang harus mereka kuasai. Di samping itu, dosen juga harus menyampaikan indikator- 
indikator ketercapaian kompetensi tersebut untuk mengukur tingkat keberhasilan mahasiswa dalam mencapainya.

b) Tahap 2: Presentasi Materi

Pada tahap penyajian materi, dosen telah menciptakan momentum awal pembelajaran. Keberhasilan proses pembelajaran dapat dimulai dari sini. Pada tahap inilah, dosen harus berhasil memberi motivasi pada beberapa mahasiswa yang kemungkinan masih belum siap.

c) Tahap 3: Penyajian Gambar Pada tahap ini, dosen menyajikan gambar dan mengajak mahasiswa untuk terlibat aktif dalam proses pembelajaran dengan mengamati setiap gambar yang ditunjukkan. Dengan gambar, pengajaran akan hemat energi, dan mahasiswa juga akan lebih mudah memahami materi yang diajarkan. Dalam perkembangan selanjutnya, dosen dapat memodifikasi gambar atau menggantinya dengan vidio atau demontrasi kegiatan tertentu.

d) Tahap 4 : Pemasangan Gambar Pada tahap ini, dosen menunjuk/memanggil mahasiswa secara bergantian untuk memasang gambar-gambar secara berurutan dan logis. Dosen juga bisa melakukan inovasi, karena penunjukan secara langsung kadang kurang efektif sebab mahasiswa cenderung merasa tertekan. Salah satu caranya adalah dengan undian, sehingga mahasiswa merasa memang harus benar-benar siap untuk menjalankan tugas yang diberikan.

e) Tahap 5: Penjajakan

Tahap ini mengharuskan dosen untuk menanyakan kepada mahasiswa tentang alasan/dasar pemikiran dibalik urutan gambar yang disusunnya. Setelah itu, mahasiswa bisa diajak untuk menemukan rumus, tinggi, jalan cerita, atau tuntutan kompetensi dasar berdasarkan indikator-indikator yang ingin dicapai. Dosen juga bisa mengajak sebanyak mungkin mahasiswa untuk membantu sehingga proses diskusi menjadi semakin menarik.

Tahap 6 : Penyajian Kompetensi Berdasarkan komentar atau penjelasan atas urutan gambar-gambar, dosen bisa mulai menjelaskan lebih lanjut sesuai dengan kompetensi yang ingin dicapai. Selama proses ini, dosen harus memberikan penekanan pada ketercapaian kompetensi tersebut. Di sini, dosen bisa mengulangi, menuliskan, atau menjelaskan gambargambar tersebut agar mahasiswa mengetahui bahwa sarana tersebut penting dalam pencapaian kompetensi dasar dan indikator-indikator yang telah ditetapkan. 
f) Tahap 7 : Penutup

Di akhir pembelajaran, dosen dan mahasiswa saling berefleksi mengenai apa yang telah dicapai dan dilakukan. Hal ini dimaksudkan untuk memperkuat materi dan kompetensi dalam ingatan mahasiswa.

Menurut Huda (2013:239), kelebihan dan kelemahan model pembelajaran picture and picture antara lain:

a) Kelebihan Model Cooperative Learning Tipe Picture And Picture

1) Dosen lebih mengetahui kemampuan masing-masing mahasiswa;

2) Mahasiswa dilatih berpikir logis dan sistematis;

3) Mahasiswa dibantu belajar berpikir berdasarkan sudut pandang suatu subjek bahasan dengan memberikan kebebasan mahasiswa dalam praktik berpikir;

4) Motivasi mahasiswa untuk belajar semakin dikembangkan; dan

5) Mahasiswa dilibatkan dalam perencanaan dan pengelolaan kelas.

b) Kelemahan Model Cooperative Learning Tipe Picture And Picture

1) Memakan banyak waktu;

2) Membuat sebagian mahasiswa pasif;

3) Munculnya kekhawatiran akan terjadi kekacauan di kelas;

4) Adanya beberapa mahasiswa tertentu yang terkadang tidak senang jika disuruh bekerja sama dengan yang lain; dan kebutuhan akan dukungan fasilitas, alat, dan biaya yang cukup memadai.

\section{Hasil Belajar}

Hasil belajar merupakan hasil atau nilai yang diperoleh mahasiswa setelah melalui berbagai proses pembelajaran meliputi mengerjakan tugas, mengikuti quis dan ujian akhir semester .

Suprijono (2013:5) menyatakan bahwa hasil belajar adalah pola-pola perbuatan, nilai-nilai, pengertian-pengertian, sikapsikap, apresiasi, dan keterampilan.

Maksudnya disini hasil belajar adalah akhir proses pembelajaran dan berkaitan dengan kemampuan mahasiswa dalam menyerap dan memahami suatu bahan yang telah diajarkan, serta proses perubahan avektif, kognitif, dan psikomotor sebagai akibat dari interaksi individu dengan lingkungan dan tindak belajar sebagai nilai yang diperoleh anak setelah menerima pengalaman belajarnya.

\section{Kerangka Pemikiran}

Kerangka pikir merupakan konsep dasar yang mendukung hubungan konsep dalam variabel penelitian. Menurut Uma Sekaran (dalam Sugiyono, 2011:60) Kerangka berfikir adalah merupakan model konseptual tentang bagaimana teori berhubungan dengan berbagai faktor yang 
telah diidentifikasikan sebagai masalah yang penting.

Berdasarkan pengertian di atas penulis menyimpulkan bahwa kerangka fikir merupakan konsep yang berisikan pemikiran dan hubungan antar variabel $\mathrm{X}=$ model cooperative learning tipe picture and picture, variabel $\mathrm{Y}=$ Hasil belajar siswa.

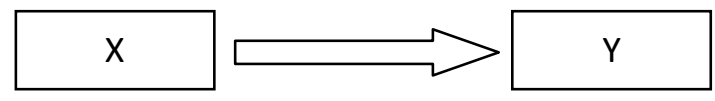

Gambar 1. Kerangka berpikir

Keterangan :

$\mathrm{X}$ : Model cooperative learning tipe picture and picture

Y : Hasil Belajar Media Pembelajaran

Untuk lebih jelasnya dapat dilihat pada kerangka pikir dilihat pada gambar di bawah ini :

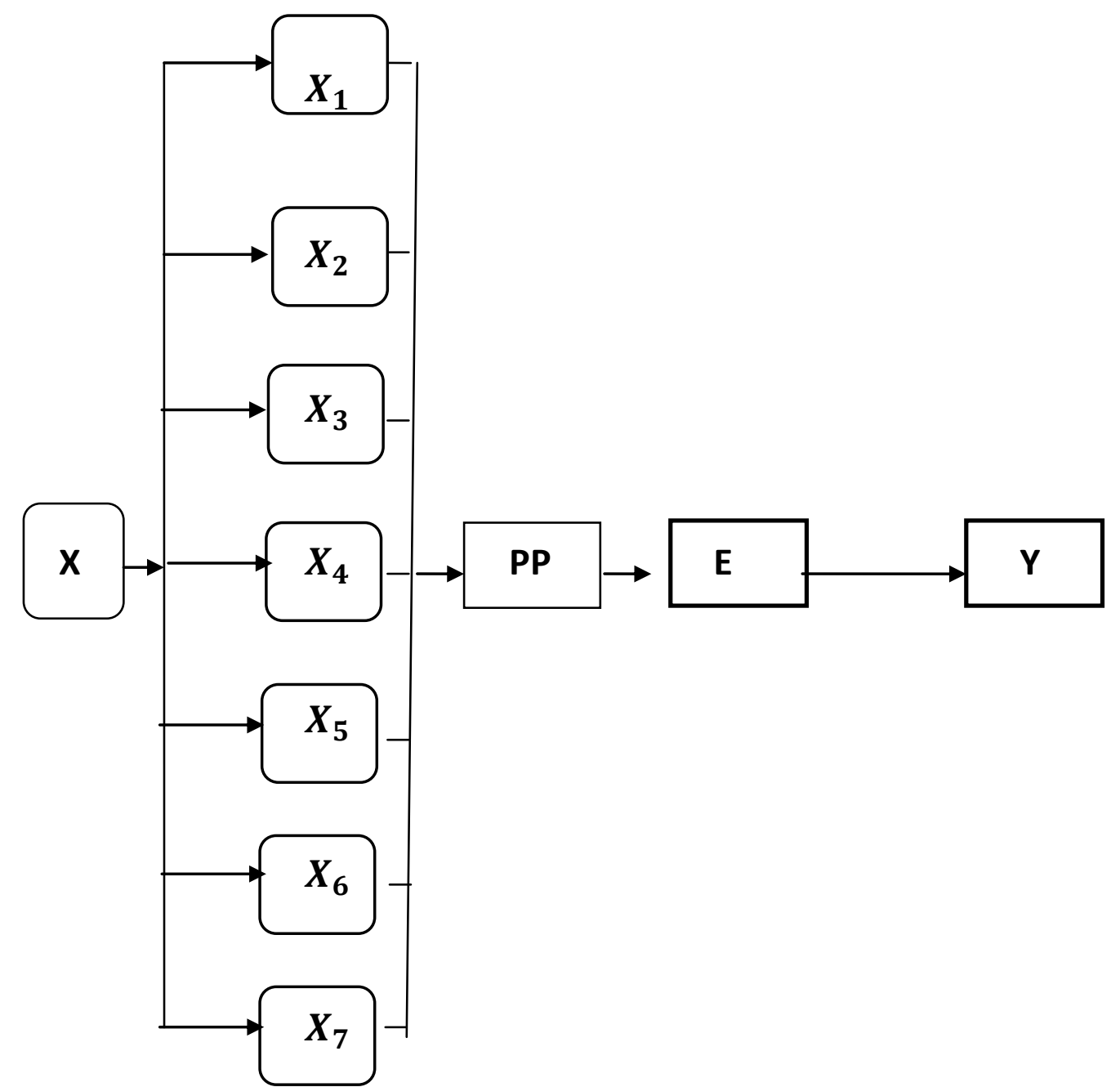

\section{Gambar 3. Kerangka Pikir}

Keterangan :

$\mathrm{X}=$ Penggunaan model cooperative learning tipe picture and picture.

$\mathrm{X}_{1}=$ Penyampaian kompetensi.

$\mathrm{X}_{2}=$ Presentasi materi.

$\mathrm{X}_{3}=$ Penyajian gambar. 
$\mathrm{X}_{4}=$ Pemasangan gambar.

$\mathrm{X}_{5}=$ Penjajakan.

$\mathrm{X}_{6}=$ Penyajian kompetensi.

$\mathrm{X}_{7}=$ Memberikan kesimpulan tentang materi yang telah disampaikan.

$\mathrm{PP}=$ Proses Pembelajaran.

$\mathrm{E}=$ Evaluasi

$\mathrm{Y}=$ Hasil Belajar.

\section{Hipotesis}

Arikunto (2006:71) menyimpulkan bahwa "Hipotesis ini merupakan jawaban yang bersifat sementara terhadap permasalahan penelitian, sampai terbukti melalui data yang terkumpul"media pembelajaran berbasis audio visual"

Berdasarkan pengertian di atas maka hipotesis dalam penelitian ini adalah "Ada pengaruh yang positif penggunaan model cooperative learning tipe picture and picture terhadap hasil belajar Media Pembelajaran mahasiswa semester IV Pendidikan Ekonomi Tahun Akademik 2014/2015”.

\section{METODE PENELITIAN}

Penelitian ini adalah bentuk dari salah satu penelitian yang bersifat kuantitatif yang bertujuan untuk meningkatkan hasil belajar media pembelajaran pada mahasiswa. Pada penelitian ini jenis penelitian yang akan dilakukan adalah pengaruh, dimana peneliti menggunakan bentuk desain quasi exsperimental design nonequivalent control group design, yang mana dalam desain penelitian ini kelompok eksperimen maupun kelompok kontrol dipilih secara random.
Penelitian ini adalah bentuk dari salah satu penelitian yang bersifat kuantitatif yang bertujuan untuk meningkatkan hasil belajar Media Pembelajaran pada mahasiswa. Penelitian ini mencari bagaimana pengaruh penggunaan model pembelajaran picture and picture terhadap hasil belajar media pembelajaran terpadu melalui metode eksperimen.

Penelitian eksperimen ini dimaksudkan untuk mengukur tingkat hasil belajar mahasiswa. Menurut Sugiyono (2008:73) menjelaskan bahwa "Desain eksperimen yang dapat dipergunakan dalam penelitian yaitu pre-experimental design, true experimental design, factorial experimental design, quasi experimental design”. Dalam penelitian ini, peneliti menggunakan bentuk desain quasi exsperimental design nonequivalent control group design yaitu pretest-posttest control group design yang mana dalam desain penelitian ini kelompok eksperimen maupun kelompok kontrol dipilih secara random, kemudian diberi pretest untuk mengetahui pengetahuan awal siswa kelompok eksperimen dan kelompok kontrol. Kelas kontrol yaitu kelas yang akan dijadikan penelitian tetapi tidak menerapkan model cooperative learning tipe picture and 
picture sedangkan kelas eksperimen yaitu kelas yang akan dijadikan penelitian dengan menerapkan cooperative learning tipe picture and picture, sehingga nantinya kita dapat membedakan bagaimana respon mahasiswa ketika kita menggunakan model cooperative learning tipe picture and picture dan tanpa menggunakan model ini.

Populasi dalam penelitian ini adalah seluruh mahasiswa semester IV pendidikan Ekonomi yang berjumlah 56 mahasiswa. Sampel diambil dengan cara cluster random sampling yang merupakan memilih sampel bukan didasarkan pada individual, tetapi lebih didasarkan pada kelompok, daerah, atau kelompok subjek, secara alami berkumpul bersama. Sampel penelitian ini menggunakan dua kelas, sampel diambil dari sebagian populasi yaitu A sebagai kelas eksperimen dengan jumlah mahasiswa sebanyak 27 mahasiswa, dan kelas B sebagai kelas kontrol sebanyak 29 mahasiswa

\section{PEMBAHASAN HASIL PENELITIAN}

Dengan demikian hipotesisnya berbunyi : Ada pengaruh yang positif penggunaan model cooperative learning tipe picture and picture terhadap hasil belajar Media Pembelajaran mahasiswa semester IV Pendidikan Ekonomi tahun akademik 2014/2015., maka hipotesisnya diterima.

Sedang nilai-nilai dari hasil belajar Media Pembelajaran mahasiswa dari evaluasi uji pretest ataupun posttest, setelah diberikan treatment menggunakan model Cooperative Learning tipe Picture and Picture dapat dilihat pada tabel berikut :

Tabel 1.Presentase Hasil Belajar Media Pembelajaran Mahasiswa semester IV Pendidikan Ekonomi tahun akademik 2014/2015.

\begin{tabular}{|c|c|c|c|c|c|c|}
\hline \multirow{2}{*}{$\begin{array}{c}\text { N } \\
\mathrm{o}\end{array}$} & $\begin{array}{c}\text { Interval } \\
\text { Nilai }\end{array}$ & Kategori & \multicolumn{2}{|c|}{ Evaluasi Uji Pretest } & \multicolumn{2}{c|}{ Evaluasi Uji Posttest } \\
\cline { 3 - 7 } & $\begin{array}{c}\text { Jumlah } \\
\text { mahasiswa }\end{array}$ & Presentase & $\begin{array}{c}\text { Jumlah } \\
\text { mahasisw } \\
\text { a }\end{array}$ & Presentase \\
\hline 1 & $\geq 70$ & Tuntas & 4 & 14,81 & 22 & 81,48 \\
\hline 2 & $<70$ & $\begin{array}{c}\text { Belum } \\
\text { tuntas }\end{array}$ & 23 & 85,19 & 5 & 18,52 \\
\hline \multicolumn{2}{|r|}{ Jumlah } & $\mathbf{2 7}$ & $\mathbf{1 0 0}$ & $\mathbf{2 7}$ & $\mathbf{1 0 0}$ \\
\hline
\end{tabular}

Sumber : Data hasil belajar Media Pembelajaran dari hasil penelitian.

Berdasarkan tabel diatas dapat diketahui bahwa pada tahap evaluasi uji pretest, bahwa mahasiswa yang mencapai tuntas belajar hanya 4 mahasiswa atau $14,81 \%$, sedangkan mahasiswa yang belum mencapai tuntas belajar 23 mahasiswa atau $85,19 \%$. Dengan demikian dapat ditemukan bahwa jumlah mahasiswa yang belum tuntas belajar atau belum mencapai standar ketuntasan yang telah ditetapkan 
masih banyak yaitu 23 mahasiswa atau $85,19 \%$ dari total keseluruhan mahasiswa sebanyak 27 mahasiswa. Dan tabel di atas dapat menunjukkan juga bahwa pada tahap evaluasi uji posttest, setelah mahasiswa mendapatkan treatment atau perlakuan menggunakan model Cooperative Learning tipe Picture and Picture yang mencapai tuntas belajar berjumlah 22 mahasiswa atau $81,48 \%$, sedangkan mahasiswa yang belum mencapai tuntas belajar berjumlah 5 mahasiswa atau $18,52 \%$, dari total keseluruhan mahasiswa sebanyak 27 mahasiswa.

Dalam penelitian ini setelah mahasiswa mendapatkan treatment atau perlakuan menggunakan model Cooperative Learning tipe Picture and Picture terhadap hasil belajar Media Pembelajaran mengalami peningkatan dilihat dari perhitungan pada evaluasi pretest dan evaluasi posttest, yaitu mahasiswa yang mencapai kriteria ketuntasan minimal pada evaluasi pretest adalah 4 mahasiswa atau $14,81 \%$ dari total keseluruhan mahasiswa sebanyak 27 mahasiswa, sedangkan mahasiswa yang mencapai kriteria ketuntasan minimal pada evaluasi posttest adalah 22 mahasiswa atau $81.48 \%$, dari total keseluruhan mahasiswa sebanyak 27 mahasiswa.

\section{KESIMPULAN}

Berdasarkan penelitian dan analisis data yang telah dilakukan oleh peneliti, maka dapat diambil kesimpulan bahwa ada pengaruh yang positif penggunaan Model Cooperative Learning Tipe Picture and Picture terhadap hasil belajar Media Pembelajaran mengenai materi memahami media pembelajaran berbasis audio visual pada mahasiswa semester IV Pendidikan Ekonomi tahun akademik 2014/2015.

Kesimpulan tersebut dibuktikan dengan meningkatnya hasil belajar mahasiswa setelah diberikan perlakuan atau treatment, dari 27 mahasiswa yang diberikan perlakuan (treatment) menggunakan model cooperative learning tipe picture and picture mahasiswa yang hasil belajar Media Pembelajaran termasuk dalam kategori tuntas berjumlah 22 mahasiswa atau $81,48 \%$, sedangkan mahasiswa yang belum mencapai tuntas belajar berjumlah 5 mahasiswa atau $18,52 \%$.

Pada pengujian dengan menggunakan rumus Regresi Linier Sederhana diperoleh $\mathrm{a}=28,4921 \mathrm{~b}=0$,8214 sehingga dengan demikian $\hat{Y}=a+b X$, adalah $\widehat{Y}=$ $28,4921+0,8214 X$. Kemudian, dari hasil analisis yang dilakukan maka terbukti bahwa ada pengaruh yang positif penggunaan model cooperative learning tipe picture and picture terhadap hasil belajar Media Pembelajaran mahasiswa 
semester IV Pendidikan Ekonomi FKIP UM Metro. Hal ini dibuktikan dengan menggunakan penghitungan analisis data dapat diketahui bahwa nilai tersebut $t_{\text {hitung }}>$ $\mathrm{t}_{\text {tabel, }}$, dan terlihat bahwa pada taraf signifikan 5\% yaitu 27,4 > 1,71. Dan pada taraf signifikan $1 \%$ yaitu $27,4>2,48$.yang dapat dilihat pada daftar $\mathrm{G}$ tabel statistik. Dengan demikian maka hipotesis diterima.

Berdasarkan kesimpulan yang peneliti uraikan di atas, dan untuk perbaikan proses pembelajaran Media Pembelajaran itu sendiri, maka sesuai dengan hasil penelitian yang telah peneliti laksanakan maka peneliti akan menyampaikan saran-saran sebagai berikut:

a) Untuk meningkatkan hasil belajar mahasiswa pada mata kuliah Media Pembelajaran, diharapkan dosen dapat menggunakan cara atau pendekatan pembelajaran yang sesuai dengan materi yang akan diberikan kepada mahasiswa sehingga dapat menciptakan suasana belajar yang kondusif, serta mampu meningkatkan hasil belajar secara maksimal. Alternatif pendekatan pembelajaran yang penulis sarankan yaitu model cooperative learning tipe picture and picture karena model pembelajaran ini membuat proses pembelajaran tidak menjadi jenuh dan dapat menciptakan suasana belajar yang menyenangkan dalam proses pembelajaran.

b) Untuk meningkatkan hasil belajar mahasiswa pada mata kuliah Media Pembelajaran, diharapkan bagi mahasiswa agar dapat lebih aktif dalam mengikuti proses pembelajaran di kelas serta memahami materi yang diberikan oleh dosen dengan lebih baik lagi dan menanyakan hal-hal yang sekiranya belum dipahami, sehingga dapat meningkatkan hasil belajar terutama pada mata kuliah Media Pembelajaran.

c) Untuk meningkatkan hasil belajar mahasiswa pada mata kuliah Media Pembelajaran, di harapkan dengan penelitain ini mudah-mudahan dapat memberikan motivasi kepada pihak sekolah untuk memanfaatkan beberapa model pembelajaran dalam proses pembelajaran, semoga dapat bermanfaat dengan baik untuk meningkatkan hasil belajar mahasiswa dalam proses pembelajaran.

\section{DAFTAR PUSTAKA}

Arikunto, Suharsimi. 2006. Prosedur Penelitian Suatu Pendekatan Praktik. Jakarta : Rineka Cipta.

Huda, Miftahul. 2013. Model-model Pengajaran dan Pembelajaran: isu-isu metodis dan paradigmatis. Yogyakarta: Pustaka Pelajar. 
Lie, Anita. 2002. Cooperative Learning Mempraktikkan Cooperative Learning di Ruang-Ruang Kelas. Jakarta: Grasindo

Santoso, Eko Budi. 2011. Model Pembelajaran Picture And Picture. (online). 10 Agustus 2014. (http://www.raseko.com/2011/05/modelpembelajaran-picture-andpicture.html

Sugiyono. 2008. Metode Penelitian Kuantitatif Kualitatif dan $R \& D$. Bandung : CV. Alfabeta.

Sugiyono. 2011. Metode Penelitian Kuantitatif Kualitatif dan $R \& D$. Bandung : CV. Alfabeta.

Susnenti, Titi. 2013. Model Pembelajaran Picture And Picture. (Online). 2 Desember2013.(http://titisusnenti.b logspot.com/2013/03/modelpembelajaran-picture-andpicture.html.)

Suprijono. 2013. Hasil Belajar dan Pembelajaran. Bandung : Tarsto 